\title{
KARAKTERISASI STRUKTUR BAWAH PERMUKAAN TANAH PEKEBUNAN PADA KEBUN CONTOH POLITANI KUPANG MENGGUNAKAN METODE GEORADAR
}

\author{
Basry Yadi Tang ${ }^{1}$, Wahyu Dani Swari2* \\ ${ }^{1}$ Program Studi Manajemen Pertanian Lahan Kering, Jurusan Manajemen Pertanian Lahan Kering, \\ Politeknik Pertanian Negeri Kupang \\ Jalan Prof. Dr. Herman Yohanes, Kupang, Indonesia \\ ${ }^{2}$ Program Studi Pendidikan Matematika, Fakultas Keguruan dan Ilmu Pendidikan, \\ Universitas Muhammadiyah Kupang \\ Jalan K.H. Ahmad Dahlan, Kupang, Indonesia \\ Alamat e-mail: ${ }^{1}$ basrytang@yahoo.com ${ }^{2}$ wahyu_daniswari@yahoo.co.id
}

\begin{abstract}
Abstrak
Telah dilakukan penelitian pada lahan kebun contoh Politeknik Pertanian Negeri Kupang. Lahan ini memiliki luas $50 \mathrm{~km}^{2}$ dan didesain sebagai lahan contoh yang disediakan oleh pihak kampus, sebagai tempat pelaksanaan kegiatan praktikum oleh Dosen dan Mahasiswa dalam menunjang perkembangan teknologi yang kreatif dan inovatif untuk meningkatkan produktivitas pertanian. Tujuan dilakukannya penelitian ini yaitu untuk mengindentifikasi tipe sedimen tanah di permukaan dan bawah permukaan berdasarkan interpretasi data georadar. Akuisisi data pada penelitian ini dilakukan pada dua lintasan pengukuran yaitu lintasan G1 dengan panjang lintasan 390 meter dan lintasan G2 dengan panjang lintasan 400 meter dengan arah lintasan Timur-Barat. Pengumpulan data georadar dilakukan dengan konfigurasi radar reflection profiling menggunakan transducer $200 \mathrm{MHz}$ yang dilengkapi dengan receiver serta dilakukan pengambilan empat titik sampel tanah secara diagonal pada lokasi penelitian. Pada metode ini, pulsa elektromagnetik (radar) dipancarkan ke dalam tanah sehingga pulsa tersebut dapat diteruskan, dipantulkan dan dihamburkan oleh struktur lapisan tanah di bawah permukaan. Pulsa radar yang dipantulkan akan kembali ke permukaan tanah dan diterima oleh receiver yang telah dipasang di permukaan tanah. Pulsa yang terekam pada receiver inilah yang dapat diolah (prosessing) dan ditampilkan dalam bentuk rekaman pencitraan dua dimensi (2D) berupa penampang radargram. Hasil penelitian berdasarkan interpretasi penampang radargram pada lintasan G1 dan G2 menunjukkan bahwa tipe sedimen tanah pada kebun contoh Politani Kupang dari permukaan tanah sampai pada kedalaman kurang dari dua meter di bawah permukaan tanah merupakan lapisan sedimen tanah grumusol dan mediteran yang berbutir halus sampai kasar. Hasil analisis sifat fisika tanah pada lapisan permukaan dan bawah permukaan pada kebun contoh Politani Kupang memenuhi tingkat kesuburan tanah.
\end{abstract}

Keywords: Tipe Sedimen Tanah, Struktur Tanah, Metode Georadar

\begin{abstract}
This research has been carried out on the example garden land of Kupang Agricultural State Polytechnic (KASP). This land is $50 \mathrm{~km}^{2}$ and designed by KASP as the practical area for students and lecturers in order to support the development of creative and innovative technology hence the agricultural
\end{abstract}


Karakterisasi Struktur Bawah Permukaan Tanah Pekebunan pada Kebun Contoh Politani....

productivity can be increased. This study aimed to identify the deposits on the surafce and sub-surface by interpreting georadar data. There were two lines in this data acquisision, they were line G1 with 390 meters and line G2 with 400 meters, and directed East-West. The data were collected by applying reflection profiling radar configuration with tranducer $200 \mathrm{Mhz}$ which was equipped by a receiver. In addition, there were four sites for soil samples which were determined by diagonal lines on the research location. This method transmits electromagnetical radar to the subsurface then it will be straightened, reflected, and scattered by the structures of the soils. The reflected radar will be back to the surface and recorded by intalled receiver. This recorded pulse will be then processed and displayed with 2D imaging radar, radargram cross-section. The results of this study attempts that the deposits in KASP that is found in less than 2 meter depth are grumusol and mediteran type whose grains are from fine to coarse. The physical analyses discovered that the soils on the surfrace and sub-surface in KASP have met soil fertility level.

Keywords: Deposits, Soil structures, Georadar method.

\section{Pendahuluan}

Tanah merupakan bagian dari lapisan atmosfer kerak bumi dan terletak pada posisi paling atas yang menjadi bagian dari kehidupan organisme ataupun mikroorganisme. Pada dasarnya tanah tersusun atas beberapa lapisan dan mengandung berbagai unsur mineral, material organik dan material anorganik lainnya, sehingga tanah sangatlah penting sebagai penunjang kehidupan di bumi karena mendukung ketersediaan unsur hara bagi tumbuhan (Ariyanto, 2010).

Lapisan sedimen tanah terdiri atas beberapa formasi atau susunan yang terbentuk dari beberapa tingkatan dan secara spesifik dapat dibedakan secara geologi, fisika, kimia dan biologi. Jika suatu lempeng tanah dipotong secara vertikal maka penampakan lapisan tanah akan terlihat sangat jelas karena pada setiap tingkat atau lapisan memang berbeda karakteristiknya. Melalui penampakan vertikal tersebut akan terlihat tahap-tahap pembentukan sebuah tanah. Bisa dikatakan bahwa setiap lapisan tanah membentuk sebuah periode yang mana pada lapisan tanah atas merupakan hasil akhir dari pembentukan tanah, sedangkan lapisan tanah paling dalam yang biasanya berupa batuan keras merupakan awal sebelum tanah terbentuk (Ariyanto, 2010).
Keadaan formasi tanah di Wilayah Propinsi Nusa Tenggara Timur khususnya di Pulau Timor terdiri atas tanah-tanah kompleks dengan bentuk wilayah pegunungan kompleks, mediteran dengan bentuk wilayah lipatan, Grumusol dengan bentuk wilayah dataran dan Latosol dengan bentuk wilayah plato atau volkan. Struktur tanah kompleks dengan bentuk wilayah pegunungan kompleks merupakan jenis tanah yang paling luas penyebarannya di Pulau Timor.

Struktur tanah merupakan sifat yang sangat penting dan sangat erat kaitannya dengan sifat fisik tanah, seperti kemampuan tanah dalam menahan air, mudah tidaknya tanah diolah dan akhirnya berpengaruh pula pada tingkat kesuburan tanah khususnya tanah perkebunan atau tanah pertanian (Tim Asisten dan Dosen, 2010).

Banyak pakar tanah yang telah mencoba mengklasifikasikan struktur tanah, tetapi hingga sekarang belum ada klasifikasi yang dapat diterima secara umum, ini disebabkan karena belum ada metode pengukuran struktur lapisan tanah yang cukup memuaskan. Beberapa aspek struktur tanah dapat ditentukan dengan baik, namun belum ada cara untuk memberikan struktur ini secara kuantitatif. 
Perkembangan teknologi elektronika di bidang geofisika telah melahirkan metode ground penetrating radar (GPR). Pada metode ini, pulsa elektromagnetik atau radar dipancarkan ke dalam tanah. Pulsa radar diteruskan, dipantulkan dan dihamburkan oleh struktur permukaan dan anomali di bawah permukaan tanah, kemudian diterima oleh antena penerima di permukaan. Salah satu kelebihan yang dimiliki metode Georadar adalah keakuratanya dalam mendeteksi stratigrafi dan lapisan tanah (soil) bawah permukaan (Jeffrey, J. D., 2010).

Informasi tentang karakteristik struktur tanah bawah permukaan yang membutuhkan nilainilai kualitatif dan kuantitatif, merupakan masukan yang sangat diperlukan. Oleh karena itu, usaha untuk memperoleh gambaran mengenai struktur tanah bawah permukaan perlu mendapat perhatian tersendiri. Penelitian karakterisasi struktur tanah bawah permukaan dengan metode georadar merupakan salah satu metode yang dapat diterapkan dalam upaya mengetahui tipe sedimen dan struktur tanah bawah permukaan sebagai sumber asal usul tingkat kesuburan tanah.

\section{Metode Penelitian}

Lokasi penelitian berada di area kampus Politani Kupang pada kebun Contoh Politani Kupang yang memiliki luas $50.000 \mathrm{~m}^{2}$. Data yang diambil penulis berupa data digital hasil rekaman georadar dan data sampel tanah.

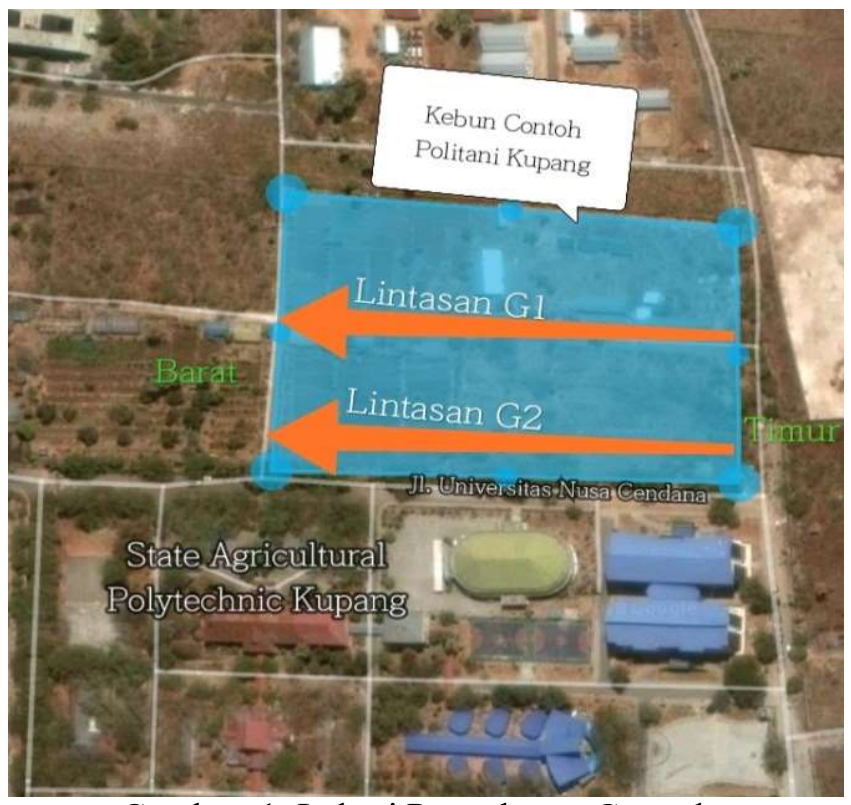

Gambar. 1. Lokasi Pengukuran Georadar

\section{Teknik Akuisisi Data}

Akuisisi data pada penelitian ini meliputi pengumpulan data georadar serta pengambilan beberapa contoh tanah yang dipilih. Pengumpulan data georadar menggunakan transducer $200 \mathrm{MHz}$, pada setiap lintasan dilakukan pengukuran topografi dengan interval yang telah ditentukan sedangkan untuk penentuan titik ukur akan dilakukan dengan menggunakan GPS Garmin 76 CSx. Berikut ini merupakan sketsa profil lintasan G1 dan G2 pada kebun contoh Politani Kupang. 
Karakterisasi Struktur Bawah Permukaan Tanah Pekebunan pada Kebun Contoh Politani....

Teknik Pengolahan Data

Penulis selanjutnya melakukan pengolahan data hasil pengukuran sesuai dengan diagram alir pengolahan data yang telah dibuat pada Gambar 4.

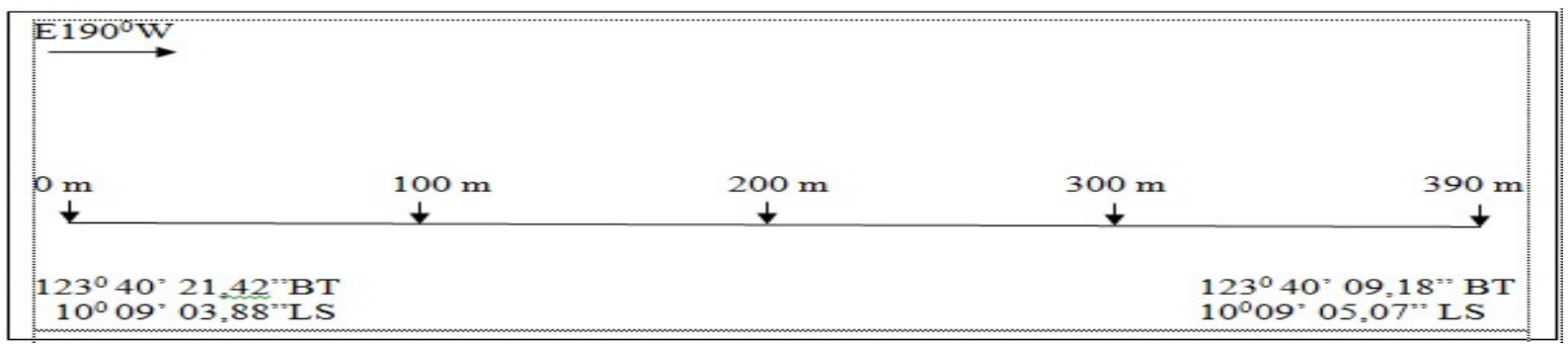

Gambar. 2. Sketsa Lintasan Pengukuran G1

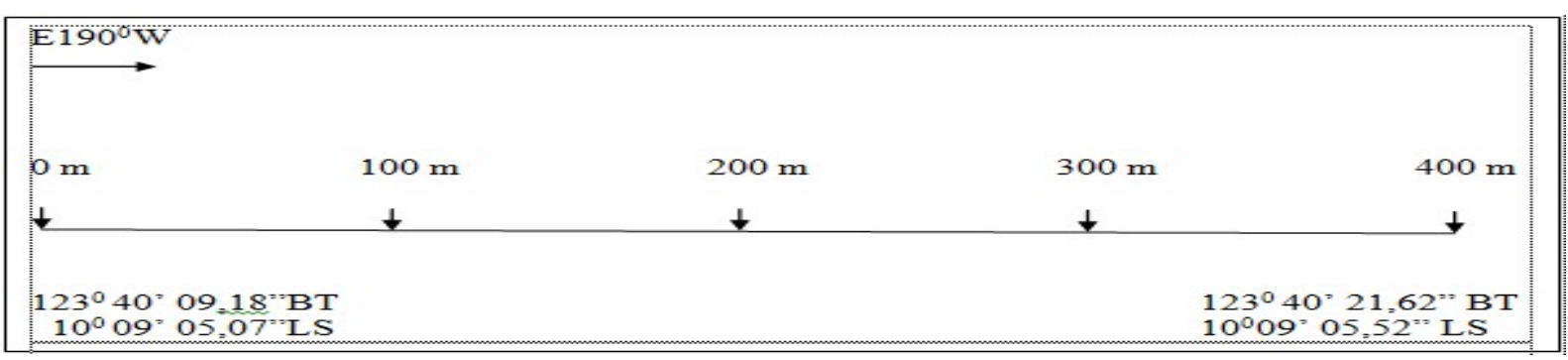

Gambar. 3. Sketsa Lintasan Pengukuran G2

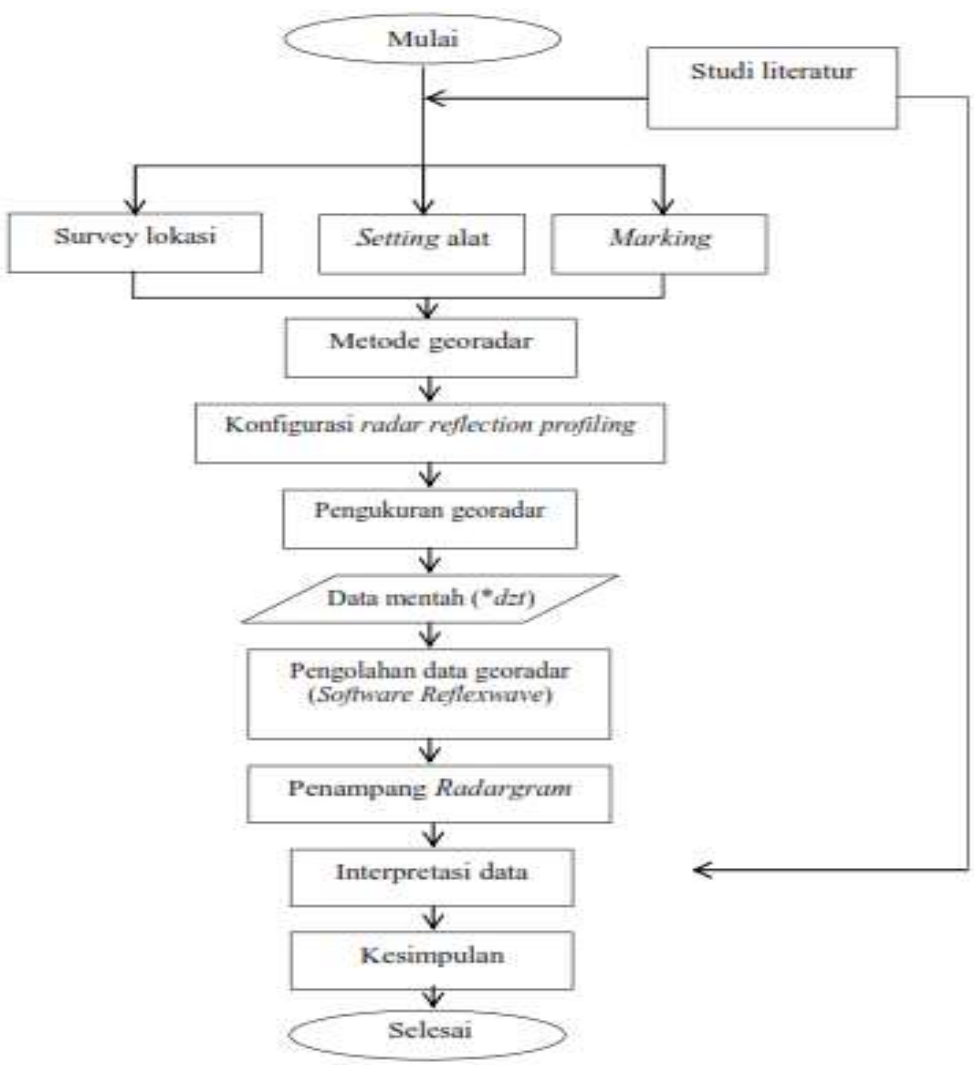

Gambar. 4. Sketsa Tahapan Pengolahan Data 


\section{Teknik Analisis Data}

Penulis menganalisis data penelitian sesuai dengan sketsa pengolahan data dan diagram alir yang telah dibuat (Yulius, 2010; Oktafiani, 2010). Dalam menganalisis data georadar dilakukan dengan mengidentifikasi tiap fasies radargram, yang dikelompokkan dalam unit radar sehingga dapat ditentukan tipe sedimen bawah permukaan (Beres and Haeni, 1991). Penulis mencoba melihat keterkaitan antara parameter yang ada yang didasarkan pada kondisi geologi regional daerah penelitian serta menarik kesimpulan dari hasil penelitian tersebut.
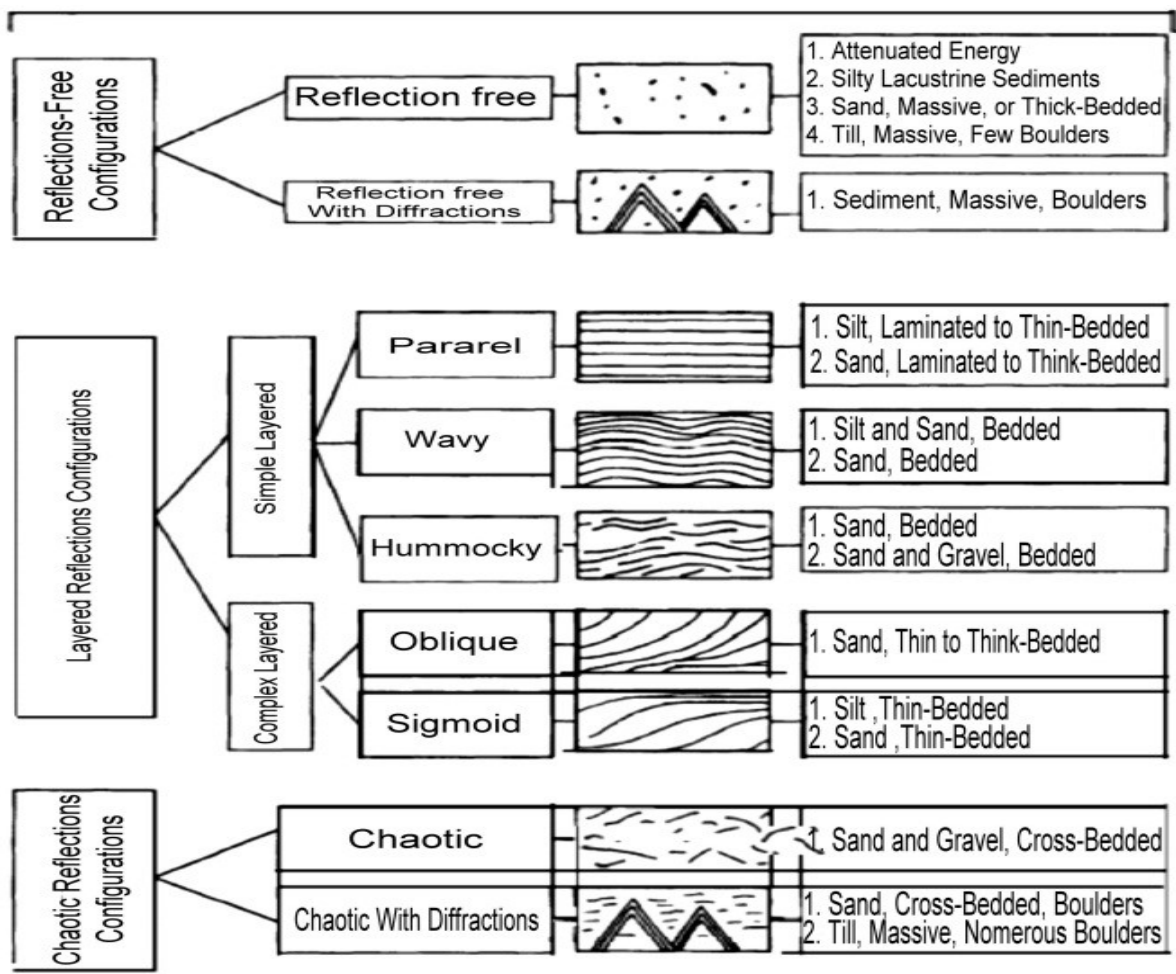

Gambar 5. Penentuan tipe sedimen bawah permukaan (Beres, M., and Haeni, F. P., 1991)

\section{Hasil dan Pembahasan}

Hasil pengolahan data ini merupakan hasil pengolahan data dengan menggunakan transducer berfrekuensi $200 \mathrm{MHz}$, pada kedalaman maksimum yang dicapai \pm 10 meter. Frekuensi ini memberikan penampang radargram yang lebih jelas dalam merepresentasikan kondisi bawah permukaan tanah dangkal (Loke, M.H., 2004). Penampang radargram yang diperoleh memberikan reflektor yang berbeda-beda untuk setiap lapisan yaitu, reflektor yang paralel menerus dengan amplitudo yang cukup tinggi, reflektor dengan subparalel menerus dan tidak menerus dengan amplitudo bervariasi dari amplitudo menengah sampai dengan amplitudo tinggi, adapun bidang yang bebas reflektor dengan amplitudo rendah serta pola konfigurasi reflektor yang bersifat chaotic (random) dengan amplitudo rendah. Berbagai pola konfigurasi tersebut dapat mengindikasikan jenis lapisan tanah di bawah permukaan dangkal. Penentuan tipe sedimen tanah dari penampang radargram yang diperoleh, mengacu pada gambar 4 . 
Karakterisasi Struktur Bawah Permukaan Tanah Pekebunan pada Kebun Contoh Politani....

Berikut ini merupakan hasil pengolahan data menggunakan software reflexwave untuk

lintasan G1 dan G2 pengukuran di kebun contoh politani Kupang.

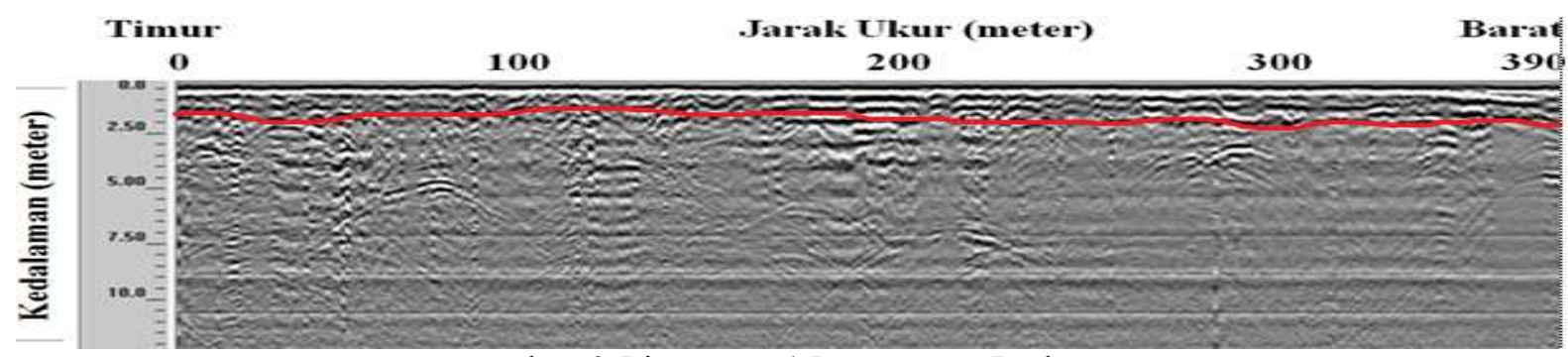

Gambar 6. Lintasan G1 Penampang Radargram

Rekaman unit GPR lintasan G1 pada gambar di atas dengan arah lintasan Timur-Barat memperlihatkan konfigurasi reflektor paralel menerus (paralel). Konfigurasi reflektor tersebut mencirikan bahwa pada lapisan tanah dari permukaan tanah pada kedalaman 0 sampai dengan kurang dari 2 meter merupakan lapisan sedimen mediteran yang berbutir halus sampai kasar, terdiri atas lempung berdebu dan lempung berpasir dengan struktur tanah granular. Pada kedalaman 2 meter sampai 9 meter terlihat adanya reflektor chaotic with diffraction yang mengindikasikan bahwa lapisan tanah tersebut merupakan lapisan sedimen kuarter yaitu lempung berkerikil dengan struktur tanah granular. Sedangkan pada kedalaman 9 meter ke bawah tidak menunjukkan adanya reflektor sehingga dapat dikatakan bahwa pada lapisan ini memiliki struktur tanah yang gumpal dan padat.

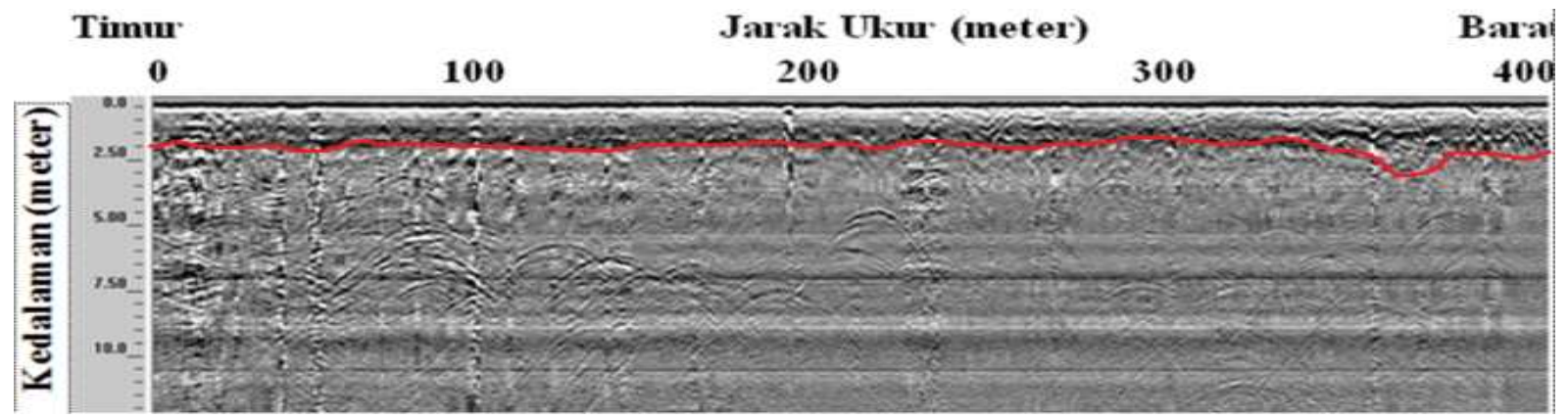

Gambar 6. Lintasan G2 Penampang Radargram

Berdasarkan hasil penampang radargram pada lintasan G2 dengan arah lintasan pengukuran berarah Timur-Barat, menggambarkan kondisi bawah permukaan tanah yang ditunjukkan oleh konfigurasi reflektor paralel menerus sepanjang lintasan pengukuran. Pada penampang ini memperlihatkan bahwa sampai pada kedalaman kurang dari 2 meter merupakan lapisan sedimen grumusol yang terdiri atas perselingan lempung dan debu yang memiliki strukur tanah granular dan gumpal membulat. Pada kedalaman 2 meter kebawah menunjukkan adanya reflektor chaotic with diffraction yang mengindikasikan lapisan sedimen kuarter yang terdiri atas gravel dan pasir dengan struktur tanah yang cukup massive akibat pembebanan dari top soil di permukaan.

Hasil interpretasi kedua penampang radargram tersebut menunjukkan bahwa 
hampir pada kedalaman yang sama yaitu kurang dari 2 meter merupakan lapisan tanah sedimen kuarter (grumusol dan mediteran) yang terdiri atas perselingan lempung, pasir dan debu. Dengan jenis struktur tanah granular dan gumpal membulat. Bahkan dapat teramati secara langsung di permukaan tanah dengan konsistensi tanah pada kondisi basah agak lekat dan plastis, pada kondisi lembab teguh dan gembur dan pada kondisi kering dimulai dari lunak sampai keras. Hal ini dapat dilihat pada tabel hasil analisis sifat fisik tanah seperti berikut :

Table 1. Analisis Sifat Fisika Tanah

\begin{tabular}{cccccccccc}
\hline Sampel & $\begin{array}{c}\text { Density } \\
\left(\mathrm{g} / \mathrm{cm}^{3}\right)\end{array}$ & $\begin{array}{c}\text { Porosity } \\
(\%)\end{array}$ & $\begin{array}{c}\text { Permeability } \\
(\mathrm{cm} / \mathrm{h})\end{array}$ & PH & Texture & Structure & Basah & Lembab & Kering \\
\hline $\begin{array}{c}\text { Lokasi } \\
1\end{array}$ & 1.18 & 55.35 & 5.86 & 6.63 & $\begin{array}{c}\text { Lempung } \\
\text { Berdebu }\end{array}$ & $\begin{array}{c}\text { Gumpal } \\
\text { Membulat }\end{array}$ & $\begin{array}{c}\text { Agak } \\
\text { Lekat }\end{array}$ & Teguh & Keras \\
\hline $\begin{array}{c}\text { Lokasi } \\
2\end{array}$ & 1.13 & 57.18 & 4.72 & 6.62 & $\begin{array}{c}\text { Lempung } \\
\text { Berdebu }\end{array}$ & Granular & $\begin{array}{c}\text { Agak } \\
\text { Lekat }\end{array}$ & Teguh & Keras \\
\hline $\begin{array}{c}\text { Lokasi } \\
3\end{array}$ & 1.04 & 60.79 & 7.95 & 6.59 & $\begin{array}{c}\text { Lempung } \\
\text { Berdebu }\end{array}$ & Granular & $\begin{array}{c}\text { Agak } \\
\text { Lekat }\end{array}$ & Gembur & Agak \\
\hline $\begin{array}{c}\text { Lokasi } \\
4\end{array}$ & 1.08 & 59.13 & 10.34 & 6.58 & $\begin{array}{c}\text { Lempung } \\
\text { Berpasir }\end{array}$ & Granular & $\begin{array}{c}\text { Agak } \\
\text { Lekat } \\
\text { dan }\end{array}$ & Gembur & Agak \\
\hline
\end{tabular}

Pengambilan sampel tanah di ambil secara diagonal dengan 4 titik lokasi pengambilan sampel tanah. Hasil analisis untuk setiap sampel tanah menunjukkan bahwa keadaan tanah pada kebun contoh Politani Kupang memenuhi tingkat kesuburan tanah secara fisik. Jadi tanah yang benar-benar subur itu apabila didukung oleh faktor-faktor pertumbuhan, salah satu diantaranya sifat fisik tanahnya juga dalam kondisi yang baik.

\section{Kesimpulan}

Hasil penelitian berdasarkan interpretasi penampang radargram menunjukkan bahwa struktur tanah pada kebun contoh Politani Kupang dari permukaan tanah sampai pada kedalaman kurang dari 2 meter di bawah permukaan tanah merupakan lapisan sedimen tanah grumusol dan mediteran yang berbutir halus sampai kasar. Hasil Identifikasi sifat fisika tanah pada lapisan permukaan dan bawah permukaan yang berperan dalam kontribusi bagi kesuburan tanah pada kebun contoh Politani Kupang memenuhi tingkat kesuburan tanah secara fisik.

\section{Daftar Pustaka}

Ariyanto, Dwi., 2010. Struktur Tanah. Http://ariyanto staff.pertanian.uns.ac .id// Diakses pada tanggal 15 Januari 2018, pukul 20.00 WITA

Beres, M., and Haeni, F. P., 1991, Application of Ground Penetrating Radar Methods in Hydrogeologic Studies, Ground Water, Vol. 3, No. 29, 375-386.

Jeffrey, J. D., 2010, Ground Penetrating Radar Fundamental. Department of Geologycal Sciences, The Ohio University

Loke, M.H., 2004, Tutorial: 2-D and 3-D Electrical Imaging Surveys for 
enviromental and engineering studies, Penang, Malaysia.

Oktafiani, F., Sulistyaningsih., dan Nurwijayanto Y., 2010, Sistem Ground Penetrating Radar Untuk Mendeteksi Benda-Benda Dibawah Permukaan Tanah, LIPI, Bandung.

Tim Asisten dan Dosen, 2010. Penuntun Dasar-Dasar Ilmu Tanah. Jurusan Ilmu Tanah, Fakultas Pertanian, Universitas Hasanuddin, Makassar.

Yulius, M, Yudi., Wahyu, Yuyu., dan Oktafiani, F, 2010, Studi Pemrosesan dan Visualisasi data Ground Penetrating Radar, LIPI, Bandung. 
